\title{
Impact of early weaning on constituents and nutritional values of camel milk in modern system
}

\author{
Ayman Balla Mustafa ${ }^{\text {* }}$, Asim Faraz ${ }^{2}$, Douglas Baum ${ }^{3}$, Abdalla Elgenaidi $^{1}$, Mohanad Bashari ${ }^{4}$, \\ Adukali Alkaskas ${ }^{1}$ and Ahmed Elhag ${ }^{5}$ \\ ${ }^{1}$ Therapeutic Nutrition Department, Faculty of Nursing and Health Sciences, Misurata University, Misurata, Libya \\ ${ }^{2}$ Deparetment of Livestock and Poultry Production, Bahauddin Zakariya University, Multan, Pakistan \\ ${ }^{3}$ Independent Researcher, 123 CR 3360 Valley Mills, Texas 76689, USA \\ ${ }^{4}$ Department of Food Science and Human Nutrition, College of Applied and Health Sciences, \\ A'Sharqiah University, Ibra, Sultanate of Oman \\ ${ }^{5}$ Faculty of Veterinary Medicine, University of Gadarif, Gadarif, Sudan
}

\begin{abstract}
Background: Camel milk is very suitable for human nutritional requirements, and its composition has similarities to mother's milk. Many scientific researches focusing on the myth of nutritional and therapeutic properties of camel milk have been brought to public attention.

Aim: This study aims to clarify the impact of early weaning on constituents and nutritional values of the milk of camels reared under a modern farming system during four months postpartum.

Methods: Eight lactating camels and eight calves were selected immediately after calving and were assigned to two equal groups under a semi-intensive system in a farm. In the early weaning group (G1), all the calves were allowed to freely suckle their mother's teats from birth to 30 days postpartum. Afterward, the calves were used to stimulate milk letdown for each of the camels' teats for a few seconds before the milking procedure. While in the late weaning group (G2), the calves freely suckled their mother's teats up to 80 days postpartum. Afterward, the calves were restricted from suckling and were used mainly to stimulate milk letdown for the milking procedure. Collection of milk samples started in the 2nd week of postpartum and continued over biweekly intervals up to 16 weeks to determine major fat, protein, lactose, solid non-fat (SNF), and density percentages.

Results: The results revealed significant differences in fat, lactose, and density content between groups. We reported significant increases in the percentages of fat, lactose, protein, and SNF levels, besides fluctuations in density with the advancement of the lactation stage.

Conclusion: In the early weaning group, the dams produced milk containing high levels of fat and SNF compared to the lactating dams in the late weaning group.

Keywords: Dromedary camel, Early weaning, Milk constituents, Modern system, Nutritional value.

\section{Introduction}

Camels are important dairy animals in arid lands and their milk is an essential food for the sustenance of people. In pastoral conditions, milk can be consumed either fresh in its raw state without heat treatment or in varying degrees of sourness (Abdelrahman et al., 2011). Camel milk is a complex mixture of fat, protein, lactose, minerals, vitamins, and miscellaneous constituents dispersed in water. The wide variation in the constituents of camel milk is attributed to some factors such as parity, season, and physiological stage. The data on the physiological change of the main components of camel milk are very scarce (Konuspayeva et al., 2009b). Arab et al. (2019) carried out studies on camel rearing in the sedentary system, and found that the lactose, solid non-fat (SNF), total solids, and protein contents were higher when compared to that in the nomadic production system. The variation might be

due to the different feeding and management systems. Furthermore, in the sedentary production system, shecamels were fed a supplement of concentrate ration that altered the composition of milk. Alwan and Zwaik (2014) reported the variation in the chemical composition of camel rearing in farm conditions and desert systems, and found that the significant effects on water, lactose, ash, and total solids may be attributed to factors such as age, number of calves, management, stage of lactation, and sampling technique. Camel milk composition was found to be less stable than other species, such as bovine milk. However, variations observed in camel milk composition can be attributed to several factors, such as analytical measurement procedures, geographical locations, feeding conditions, and samples taken from different breeds, in addition to other factors, which include the stage of lactation, age, and number of calves (Khaskheli et al., 2005).
\end{abstract}


Milk protein, fat, lactose, and ash content were all affected by season. Therefore, protein, fat, and ash content were higher during summer (May-July) and decreased during winter (October-January). However, lactose content showed an opposite trend, being higher during the rainy season and decreasing during the summer season in Sudan (Bakheit et al., 2008). In Saudi Arabia, Abdelgadir et al. (2013) reported no significant effect of parity, gestation length, or calf birth weight on milk constituents.

A strong positive correlation was found between fat and protein contents (Haddadin et al., 2008). The composition of camel milk varies with the quality and availability of feed, as well as differences in husbandry practices. However, interventions to improve the production practices through better hygiene and medical care of camels and their milk are needed. We hypothesize that the early weaning practice may accelerate the estrus cycle and lead to changes in milk constituents. Hence, early weaning can be an interesting way to reduce the calving interval and increase the productivity of camels. Thus, this study aims to elucidate the impact of some husbandry practices and early weaning on nutritional values and constituents of camel milk under the modern farming system.

\section{Material and Methods \\ Experimental animals}

Eight lactating one-humped camels, eight calves, and one mature male camel were chosen from a mixed herd of camels on the farm of the Camel Research Centre, University of Khartoum, Sudan. Camels were clinically healthy and the criteria adopted for the selection of dams were similarity in body weight, age, and order of breed. The age of the she-camels used in the experiment ranged from 6 to 17 years, wherein the average mean of dam body weight was $396.57 \pm 45.86 \mathrm{~kg}$. This study was carried out according to the rules governing the use of experimental animals as acceptable internationally. All the experimental animals were herded in closed pens and set free for 5 hours during daylight (9:00 am-2:00 pm) to graze and browse outdoor, then returned to the pens each afternoon. The dams were supplemented with ration feed, which included $2 \mathrm{~kg} /$ head/day of concentrates in addition to roughages, such as sorghum straw, as shown in Table 6. The water source was available daily, and healthcare and parasites control were practiced as needed. In this modern system, the animals were brought for browsing on irrigated schemes on limited areas around the farm, approximately $700-1,200 \mathrm{~km}$ from the farm site, where they selected preferable plants, thorns, and herbs by themselves from the available range.

\section{Experimental design}

Eight lactating camels and their calves were selected and divided into two groups (G1 and G2), while the mature male camel (Al Fahal) was separated.
In group one (G1), all the calves were allowed to freely suckle from birth to 30 days postpartum. Afterward, they calves were weaned early and used to stimulate milk letdown for each of the she-camel's teats for a few seconds before the milking procedure. The remaining milk in the udder quarters was consumed by the calf immediately after hand milking. After 60 days, all the four quarters of the udder were milked completely, and the calves were used only to stimulate milk "letdown" by suckling for a few seconds, then returning to the pens near their dams that were restricted from breastfeeding. In group two (G2), the calves were allowed to freely suckle up to $75-80$ days postpartum. Afterward, the calves were weaned and were used to stimulate milk letdown by sucking each of the she-camels teats for a few seconds before the milking procedure, the remaining milk in the other quarters was left to be consumed by the calf. Calves remained with their dams all day and were separated during the night hours into special pens. Restriction of suckling was applied by a traditional method called "Shemal", which is adopted by many herders in Sudan. Shemal is made from nylon or cotton material, and it is a bag used to cover the mouth of the calf to restrict it from suckling.

\section{Milk samples collection}

Milk samples were collected in sterile glass bottles (40 $\mathrm{ml})$. The collection of samples was started in the 14th day postpartum and continued over biweekly intervals up to the 4th month postpartum. Hand milking was carried out twice a day, with the first milking at 8:00 am every morning and the second milking at 4:00 pm every afternoon. These samples were immediately delivered to the Dairy Lab in the Faculty of Animal Production, University of Khartoum, Sudan, for laboratory analysis. Mastitis accidence and calf mortality

During the experiment, one dam had mastitis and internal parasites, whereas one calf's sudden death was documented at 2 months of age. In such cases, the dams were discarded from the experiment.

\section{Laboratory analysis of milk composition}

The fat, protein, lactose, SNF, and density percentages were determined biweekly for 16 weeks postpartum by an automatic Lactoscan SP milk analyzer device (Lactoscan SP, Model-90, Europe).

\section{Statistical analysis}

All the data were subjected to the general linear model using statistics version 8 software program; variations of means regarding treatments and weeks were calculated. Least Significant Difference test was used to differentiate the means (Free Software Foundation, Boston, MA).

\section{Ethical approval}

The protocol for this study was approved by the Ethics Committee of Applied Sciences, which is authorized by the Faculty of Graduate Study, University of Khartoum. Thereafter, the experiment was conducted in the Camel Research Centre at the University of Khartoum. 


\section{Results}

The results shown in Table 1 elucidate the fat contents of camel milk for G1 and G2 during the experimental period. The fat content reached a peak value $(7.99 \%$ $\pm 0.69 \%$ ) within week 10 and 12 postpartum, and the results revealed that the fat content in week 10 and 12 postpartum was significantly high $(p<0.01)$ in G1 when compared to that in G2. Obviously, the fluctuation in fat contents was realized within 16 weeks in G2 group, and they ranged from $2.52 \% \pm 0.60 \%$ to $4.2567 \% \pm$ $0.69 \%$, while a slight increase in fat content with the advancement of lactation declined in weeks 14 and 16 . The current study noted significantly $(p<0.05)$ higher fat contents in the milk of the animals in G1 $(4.95 \% \pm$ $0.25 \%)$ when compared to G2 $(3.53 \% \pm 0.22 \%)$ within 4 months postpartum. These are shown in Figures 1-3. Table 2 presents the results of the average lactose content in camel milk for 4 months postpartum in G1 and G2. There was no significant difference $(p>0.05)$ in the lactose content during the 4 months, although there was a slight increase with the advancement of the lactation stage. The results prove that a significantly ( $p$ $<0.05)$ higher value of lactose was reported in G2 (4.96 $\pm 0.24)$ when compared to that in G1 $(4.88 \% \pm 0.29 \%)$ for the entire experimental period.

The results presented in Table 3 indicate the milk protein content for both the groups at early and late weaning periods with the lack of variation $(p>$ 0.05) in protein content between two groups for the entire experimental period. Clearly, the protein level was slightly increased with the advancement in the lactation period, especially in G2 when compared to that in G1.

Table 4 shows the SNF content of milk produced by G1 and G2 during the experimental period. In this study, there was no significant $(p>0.05)$ different in SNF content in G1 when compared to G2. The increase in SNF content coincided with the advancement in the lactation stage during the experimental period. Moreover, the results revealed that SNF content was realized during the first 6 weeks postpartum (8.63 $\pm 0.13-8.67)$, and was significantly $(p<0.05)$ lower during the weeks that followed $(9.13 \pm 0.15-9.55 \% \pm$ $0.15 \%$ ), as shown in Figures 2 and 3.

The results presented in Table 5 shows the density of milk in G1 and G2. The milk density was significantly

Table 1. Variations (Mean \pm SE) in fat content (\%) of milk during the experimental period (2nd-16th week postpartum) under the modern system.

\begin{tabular}{lccccccccc}
\hline Treatment & 2nd week & 4th week & 6th week & 8th week & $\begin{array}{c}\text { 10th } \\
\text { week }\end{array}$ & $\begin{array}{c}\text { 12th } \\
\text { week }\end{array}$ & $\begin{array}{c}\text { 14th } \\
\text { week }\end{array}$ & $\begin{array}{c}\text { 16th } \\
\text { week }\end{array}$ & Overall \\
\hline \multirow{2}{*}{ G1 } & $1.83 \pm$ & $2.52 \pm$ & $5.04 \pm$ & $3.48 \pm$ & $7.99 \pm$ & $7.99 \pm$ & $4.59 \pm$ & $6.17 \pm$ & $4.95 \pm$ \\
& $0.69 \mathrm{f}$ & $0.69 \mathrm{ef}$ & $0.69 \mathrm{bc}$ & $0.69 \mathrm{cdef}$ & $0.69 \mathrm{a}$ & $0.69 \mathrm{a}$ & $0.69 \mathrm{bcd}$ & $0.69 \mathrm{ab}$ & $0.25 \mathrm{a}$ \\
\multirow{2}{*}{ G2 } & $3.52 \pm$ & $3.05 \pm$ & $4.08 \pm$ & $2.52 \pm$ & $3.02 \pm$ & $3.72 \pm$ & $4.07 \pm$ & $4.26 \pm$ & $3.53 \pm$ \\
& $0.60 \mathrm{cdef}$ & $0.60 \mathrm{def}$ & $0.53 \mathrm{cde}$ & $0.60 \mathrm{ef}$ & $0.69 \mathrm{def}$ & $0.60 \mathrm{cde}$ & $0.60 \mathrm{cde}$ & $0.69 \mathrm{bcde}$ & $0.21 \mathrm{~b}$ \\
\multirow{2}{*}{ Overall } & $2.68 \pm$ & $2.78 \pm$ & $4.56 \pm$ & $3.0 \pm$ & $5.50 \pm$ & $5.86 \pm$ & $4.33 \pm$ & $5.22 \pm$ & $4.24 \pm$ \\
& $0.45 \mathrm{c}$ & $0.45 \mathrm{c}$ & $0.4 \mathrm{~b}$ & $0.45 \mathrm{c}$ & $0.49 \mathrm{ab}$ & $0.45 \mathrm{a}$ & $0.45 \mathrm{~b}$ & $0.49 \mathrm{ab}$ & 1.85 \\
\hline
\end{tabular}

Different letters in the same column and row indicate a significant difference $(p<0.05)$

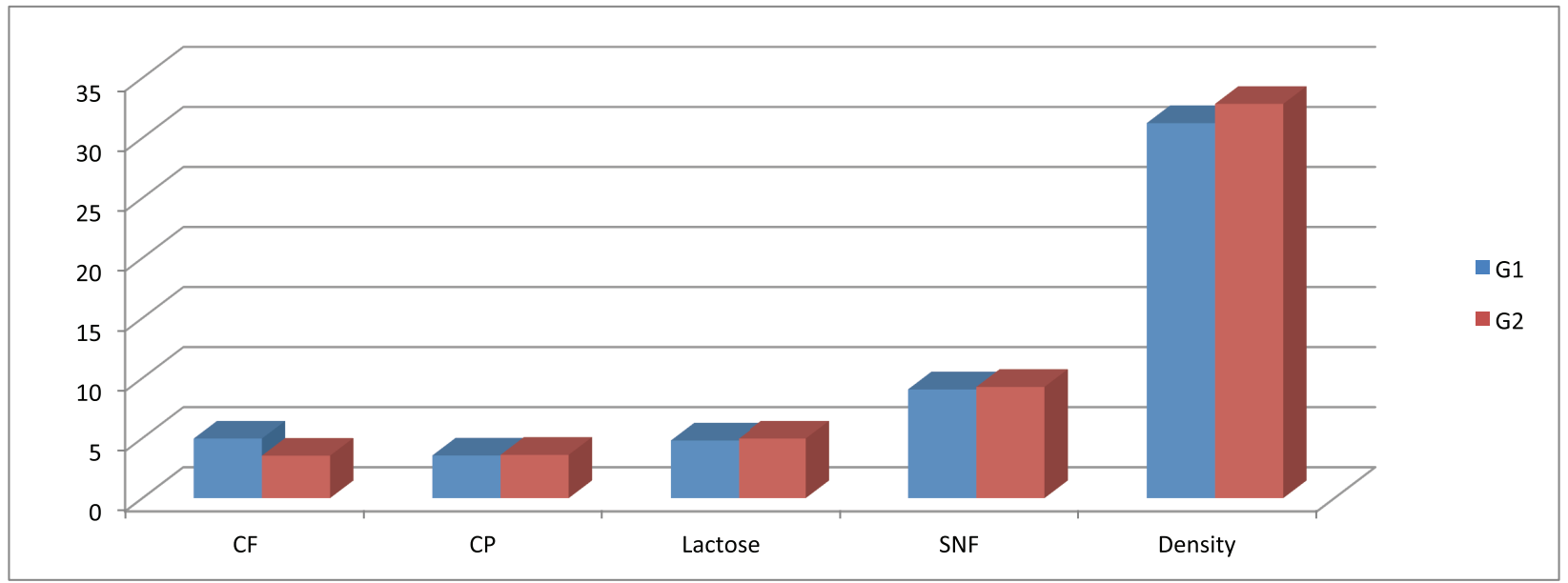

Fig. 1. Variations of average means (\%) for components of camel milk under the modern system. 


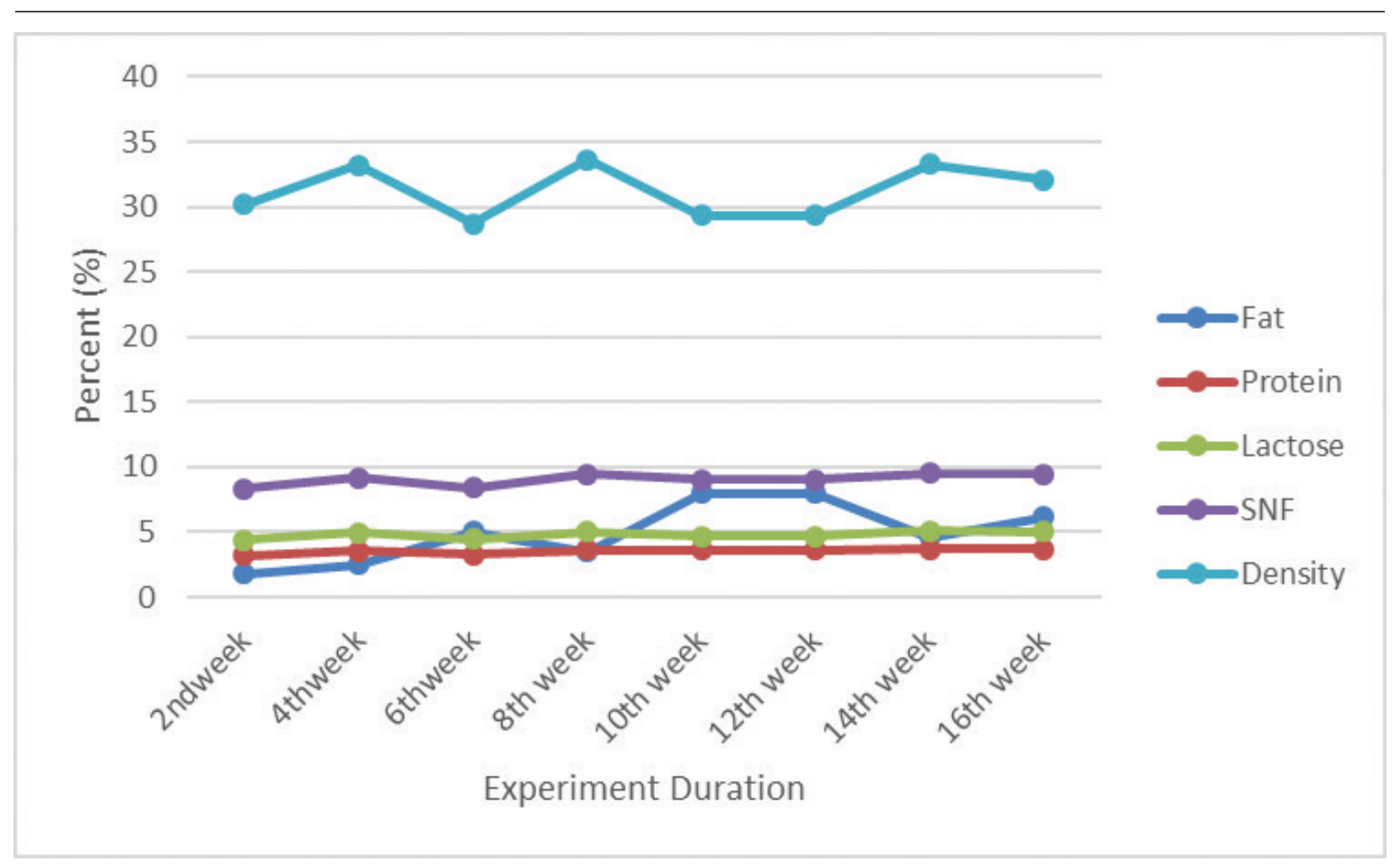

Fig. 2. Curve of the level of components of camel milk of G1 during the experimental period.

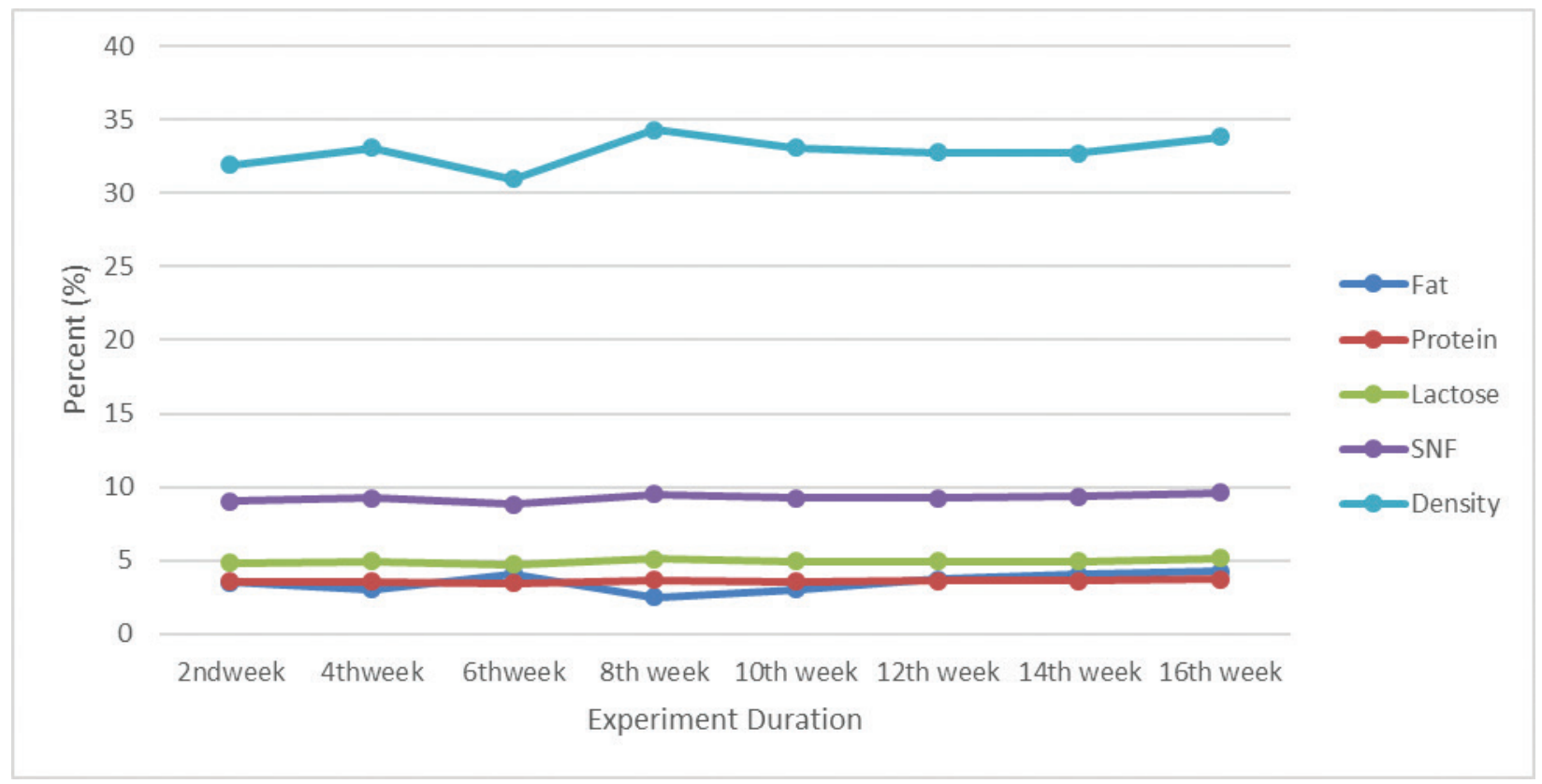

Fig. 3. Curve of the level of components of camel milk of G2 during the experimental period.

$(p<0.05)$ different in the tenth and twelfth lactation weeks in both experimental groups as shown in Figures 2 and 3 . This study noted a significantly $(p<0.05)$ higher average of milk density that was produced by $\mathrm{G} 2(32.83 \% \pm 0.26 \%)$ when compared to $\mathrm{G} 1(31.2 \% \pm 0.3 \%)$. 
Table 2. Variations (Mean $\pm \mathrm{SE}$ ) in lactose content (\%) of milk during the experimental period (2nd-16th week postpartum) under the modern system.

\begin{tabular}{lccccccccc}
\hline Treatment & 2nd week & 4th week & 6th week & 8th week & 10th week & 12th week & 14th week & 16th week & Overall \\
\hline \multirow{2}{*}{ G1 } & $4.38 \pm$ & $4.95 \pm$ & $4.46 \pm$ & $5.06 \pm$ & $4.71 \pm$ & $4.71 \pm$ & $5.07 \pm$ & $5 \pm$ & $4.78 \pm$ \\
& $0.11 \mathrm{~d}$ & $0.11 \mathrm{ab}$ & $0.91 \mathrm{~cd}$ & $0.11 \mathrm{a}$ & $0.11 \mathrm{bcd}$ & $0.11 \mathrm{bcd}$ & $0.11 \mathrm{a}$ & $0.11 \mathrm{ab}$ & $0.29 \mathrm{~b}$ \\
\multirow{2}{*}{ G2 } & $4.83 \pm$ & $4.96 \pm$ & $4.72 \pm$ & $5.11 \pm$ & $4.96 \pm$ & $4.96 \pm$ & $4.97 \pm$ & $5.14 \pm$ & $4.96 \pm$ \\
& $0.10 \mathrm{ab}$ & $0.10 \mathrm{ab}$ & $0.09 \mathrm{bc}$ & $0.10 \mathrm{a}$ & $0.11 \mathrm{ab}$ & $0.10 \mathrm{ab}$ & $0.10 \mathrm{ab}$ & $0.11 \mathrm{a}$ & $0.24 \mathrm{a}$ \\
\multirow{2}{*}{ Overall } & $4.61 \pm$ & $4.96 \pm$ & $4.58 \pm$ & $5.08 \pm$ & $4.84 \pm$ & $4.84 \pm$ & $5.02 \pm$ & $5.0717 \pm$ & $4.875 \pm$ \\
& 0.08 & 0.08 & 0.1 & 0.08 & 0.08 & 0.08 & 0.08 & 0.08 & 0.2 \\
\hline
\end{tabular}

Different letters in the same column and row indicate a significant difference $(p<0.05)$.

Table 3. Variations (Mean $\pm \mathrm{SE}$ ) in protein content (\%) of camel milk during the experimental period (2nd-16th weeks postpartum) under the modern system.

\begin{tabular}{lccccccccc}
\hline Treatment & 2nd week & 4th week & 6th week & 8th week & 10th week & 12th week & 14th week & 16th week & Overall \\
\hline \multirow{2}{*}{ G1 } & $3.2 \pm$ & $3.54 \pm$ & $3.31 \pm$ & $3.66 \pm$ & $3.6 \pm$ & $3.6 \pm$ & $3.72 \pm$ & $3.73 \pm$ & $3.55 \pm$ \\
& $0.09 \mathrm{c}$ & $0.09 \mathrm{~b}$ & $0.09 \mathrm{c}$ & $0.08 \mathrm{ab}$ & $0.09 \mathrm{ab}$ & $0.08 \mathrm{ab}$ & $0.08 \mathrm{a}$ & $0.09 \mathrm{a}$ & $0.03 \mathrm{a}$ \\
\multirow{2}{*}{ G2 } & $3.57 \pm$ & $3.58 \pm$ & $3.44 \pm$ & $3.65 \pm$ & $3.57 \pm$ & $3.6 \pm$ & $3.63 \pm$ & $3.75 \pm$ & $3.6 \pm$ \\
& $0.08 \mathrm{~b}$ & $0.08 \mathrm{~b}$ & $0.074 \mathrm{c}$ & $0.08 \mathrm{ab}$ & $0.09 \mathrm{~b}$ & $0.09 \mathrm{ab}$ & $0.08 \mathrm{ab}$ & $0.09 \mathrm{a}$ & $0.03 \mathrm{a}$ \\
\multirow{2}{*}{ Overall } & $3.38 \pm$ & $3.56 \pm$ & $3.37 \pm$ & $3.66 \pm$ & $3.58 \pm$ & $3.6 \pm$ & $3.67 \pm$ & $3.74 \pm$ & $3.6 \pm$ \\
& $0.06 \mathrm{c}$ & $0.05 \mathrm{~b}$ & $0.05 \mathrm{c}$ & $0.06 \mathrm{ab}$ & $0.06 \mathrm{ab}$ & $0.06 \mathrm{ab}$ & $0.06 \mathrm{ab}$ & $0.06 \mathrm{a}$ & 0.03 \\
\hline
\end{tabular}

Different letters in the same column and row indicate a significant difference $(p<0.05)$.

Table 4. Variations (Mean \pm SE) in SNF content (\%) of camel milk during the experimental period (2nd-16th weeks postpartum) under the modern system.

\begin{tabular}{lccccccccc}
\hline Treatment & 2nd week & 4th week & 6th week & 8th week & 10th week & 12th week & 14th week & 16th week & Overall \\
\hline \multirow{2}{*}{ G1 } & $8.31 \pm$ & $9.2 \pm$ & $8.42 \pm$ & $9.45 \pm$ & $9.02 \pm$ & $9.02 \pm$ & $9.52 \pm$ & $9.46 \pm$ & $9.05 \pm$ \\
& $0.22 \mathrm{~b}$ & $0.22 \mathrm{a}$ & $0.22 \mathrm{~b}$ & $0.22 \mathrm{a}$ & $0.22 \mathrm{a}$ & $0.22 \mathrm{a}$ & $0.22 \mathrm{a}$ & $0.22 \mathrm{a}$ & $0.08 \mathrm{a}$ \\
\multirow{2}{*}{ G2 } & $9.02 \pm$ & $9.24 \pm$ & $8.84 \pm$ & $9.49 \pm$ & $9.24 \pm$ & $9.27 \pm$ & $9.33 \pm$ & $9.64 \pm$ & $9.26 \pm$ \\
& $0.20 \mathrm{a}$ & $0.20 \mathrm{a}$ & $0.17 \mathrm{~b}$ & $0.2 \mathrm{a}$ & $0.22 \mathrm{a}$ & $0.2 \mathrm{a}$ & $0.2 \mathrm{a}$ & $0.22 \mathrm{a}$ & $0.07 \mathrm{a}$ \\
\multirow{2}{*}{ Overall } & $8.67 \pm$ & $9.22 \pm$ & $8.63 \pm$ & $9.47 \pm$ & $9.13 \pm$ & $9.15 \pm$ & $9.4 \pm$ & $9.55 \pm$ & $9.15 \pm$ \\
& $0.14 \mathrm{~b}$ & $0.14 \mathrm{a}$ & $0.13 \mathrm{~b}$ & $0.14 \mathrm{a}$ & $0.15 \mathrm{a}$ & $0.14 \mathrm{a}$ & $0.14 \mathrm{a}$ & $0.15 \mathrm{a}$ & 0.48 \\
\hline
\end{tabular}

Different letters in the same column and row indicate a significant difference $(p<0.05)$.

Table 5. Variations (Mean \pm SE) in density (\%) of camel milk during the experimental period (2nd-16th week postpartum) under the modern system.

\begin{tabular}{lccccccccc}
\hline Treatment & 2nd week & 4th week & 6th week & 8th week & 10th week & 12th week & 14th week & 16th week & Overall \\
\hline \multirow{2}{*}{ G1 } & $30.2 \pm$ & $33.2 \pm$ & $28.7 \pm$ & $33.59 \pm$ & $29.36 \pm$ & $29.36 \pm$ & $33.26 \pm$ & $32.08 \pm$ & $31.2 \pm$ \\
& $0.8 \mathrm{~b}$ & $0.8 \mathrm{a}$ & $0.8 \mathrm{~b}$ & $0.8 \mathrm{a}$ & $0.83 \mathrm{~b}$ & $0.83 \mathrm{~b}$ & $0.3 \mathrm{a}$ & $0.83 \mathrm{a}$ & $0.3 \mathrm{~b}$ \\
\multirow{2}{*}{ G2 } & $31.94 \pm$ & $33.06 \pm$ & $30.95 \pm$ & $34.29 \pm$ & $33.06 \pm$ & $32.78 \pm$ & $32.7 \pm$ & $33.84 \pm$ & $32.83 \pm$ \\
& $0.73 \mathrm{~b}$ & $0.73 \mathrm{a}$ & $0.65 \mathrm{~b}$ & $0.73 \mathrm{a}$ & $0.84 \mathrm{a}$ & $0.72 \mathrm{a}$ & $0.72 \mathrm{a}$ & $0.8 \mathrm{a}$ & $0.26 \mathrm{a}$ \\
\multirow{2}{*}{ Overall } & $31.09 \pm$ & $33.13 \pm$ & $29.83 \pm$ & $33.94 \pm$ & $31.21 \pm$ & $31.07 \pm$ & $32.97 \pm$ & $32.96 \pm$ & $32.03 \pm$ \\
& $0.54 \mathrm{~b}$ & $0.54 \mathrm{a}$ & $0.5 \mathrm{~b}$ & $0.55 \mathrm{a}$ & $0.59 \mathrm{~b}$ & $0.5 \mathrm{~b}$ & $0.55 \mathrm{a}$ & $0.59 \mathrm{a}$ & 1.96 \\
\hline
\end{tabular}

Different letters in the same column and row indicate a significant difference $(P<0.05)$ 
Table 6. Average feed composition that was provided to the camels during the experimental period.

\begin{tabular}{|c|c|c|c|c|c|c|c|}
\hline \multicolumn{8}{|c|}{ The average of feed ration (concentrate) composition } \\
\hline Samples & DM & Fat & $\mathbf{C P}$ & $\mathbf{C F}$ & Ash & NFE & ME (kcal/kg) \\
\hline Concentrate & 94.78 & 2.90 & 21.15 & 10.10 & 5.35 & 60.49 & 1.240 \\
\hline \multicolumn{8}{|c|}{ Average of roughage composition } \\
\hline Samples & DM & Fat & $\mathbf{C P}$ & $\mathbf{C F}$ & Ash & & \\
\hline Sorghum straw & 94.55 & 1.26 & 1.87 & 59.26 & 4.33 & & \\
\hline
\end{tabular}

\section{Discussion}

In this study, the early weaning method eventually influenced the milk constituents and nutritional values of camels raised in the modern farming system. These findings are similar to the data reported by Wafa and ElZubeir (2014), Riyadh et al. (2012), Hassabo (2010), Konuspayeva et al. (2009a), and Indra et al. (2003). Whereas the findings in this study are different than the findings reported by Shuiep et al. (2008), Bakheit et al., (2008), and Khaskheli et al. (2005).

In this study, we observed that the fat, lactose, and protein content had increased slightly with the advancement of the lactation stage. These findings are in agreement with the observations reported by Bakheit et al. (2008), who observed that fat, protein, and lactose increased with the advancement of first lactation. Furthermore, it is also in agreement with the studies of Sheriha (1986), Shuiep et al. (2008), and Abdelgadir et al. (2013), who stated that the milk components were elevated during the first stage of lactation, whereas high values of fat content were observed during the 4 months postpartum in this study, which is in agreement with the findings of Igbal et al. (2001), Raghvendar et al. (2004), Riek and Gerken (2006), and Zeleke (2007). In this study, wide variations between milk constituents of camels, regarding dams that were suckled by their claves (late weaning) and the others that were restricted from being suckled (early weaning), were observed. This may be attributed to the physiological process according to Sambraus (1995), who suggested that the duration of suckling and the vigor of butting or extracting milk by the calf from the gland can influence the strength of milk ejection reflex and affect milk secretion independently of suckling frequency. The results of this study reveals that high values of fat content and low values of lactose, protein, and SNF of milk were produced by camels, whose calves were early weaned (restricted from suckling). These results are in agreement with the findings of Martinez (1989) who reported a negative correlation between fat content, on one hand, and protein and lactose contents, on the other hand. The variation in fat content of milk between the two groups is indirectly related to the milk yield as described by Khaskheli et al. (2005) and Bakheit et al. (2008), who reported that during the dry season, camels can produce a high diluted amount of milk with low fat.

\section{Conclusion}

Lactating she-camels with early weaned calves, restricted from suckling, produced milk containing high levels of fat and SNF compared to the late weaning lactating she-camels that had free suckling calves. Further research is required to investigate the effect of restrictive suckling and early weaning on the physiological changes, milk productivity, and fertility of camels.

\section{Conflict of interest}

The authors declare that there is no conflict of interest. Authors'contribution

A.M.B. and A.F. designed the research. A.B.M. and A.E. formulated the plans and supervised the experiment. They also assisted in data collection and performed the experiments. A.R.E. and M.B. assisted with the lab work and statistical analysis. A.B.M., A.A., and D.B. wrote and reviewed the manuscript. All authors critically reviewed the data and the manuscript.

\section{References}

Abdelgadir, M.M., Faye, B. and Al-Mutairi, S.E. 2013. Seasonal and physiological variation of gross composition of camel milk in Saudi Arabia. Emir. J. Food Agric. 25, 618-624; doi:10.9755/ejfa. v25i8.16095

Abdelrahman, Y.M., Eisa, M.O., Mustafa, A.B. and Salih A.M. 2011. Constraints of camel pastoralists in Gadaref State, Eastern Sudan. Res. Opin. Anim. Vet. Sci. 3, 174-177.

Alwan, O.A. and Zwaik, H.B. 2014. Milk composition of Libyan Maghrebi camels (Camelus Dromedaries) reared under farm and desert conditions. International Conference on Chemical, Environment \& Biological Sciences (CEBS2014),2014 Sept 17-18, Kuala Lumpur, Malaysia.

Arab, K.L., Tarique, A.K., Aijaz, A.J., Shahnawaz, K., Qudratullah, K., Yar, M.J., Zafar, A.K., Muhammad, M.R., Abdul, S.M. and Asad, A.K. 2019. Compositional and physical properties of camel milk under nomadic and sedentary production systems. Pure Appl. Biol. 8, 1494-1498.

Bakheit, S.A., Majid, A.M.A. and Nikhala, A.M. 2008. Camels (Camelus dromedarius) under pastoral systems in North Kordofan, Sudan: seasonal and parity effects on milk composition. J. Camelid Sci. 1, 32-36. 
Haddadin, M.S.Y., Gammoh, S.I. and Robinson, R.K. 2008. Seasonal variations in the chemical composition of camel milk in Jordan. J. Dairy Res. $75,8-12$.

Hassabo, A.A. 2010. Effect of feeding system on milk yield of camel kept around the urban area in Sudan during summer. In International camel symposium. Garissa, Kenya: Held in Garissa.

Igbal, A., Gill, R.A. and Younas M. 2001. Milk composition of Pakistani camel (Camelus dromedarius) kept under station/farmers conditions. Emir. J. Agric. Sci. 13, 7-10.

Indra, P., Magatch, A. and Batsoour, L. 2003. Mongol bactrian camel [Mongol Temet]. Ulaanbaatar, Mongolia: Mongolia State University of Agriculture Publishing.

Khaskheli, M., Arain, M.A., Chaudhry, S., Soomro, A.H. and Qureshi, T.A. 2005. Physico-chemical quality of camel milk. J. Agric. Soc. Sci. 2, 164166.

Konuspayeva, G., Faye, B. and Loiseau, G. 2009a. The composition of camel milk: a meta-analysis of the literature data. J. Food Comp. Anal. 22, 95-101.

Konuspayeva, G., Faye, B., Loiseau, G., Ivashehenko, A., Meldebkova, A. and Davletov, S. 2009 b. Physiological change in camel milk composition, 1- effect of lactation stage. Trop. Anim. Health Prod. 42, 495-499.

Martinez, D. 1989. Note on the production of camel milk in the peri-urban sector in Mauritania. Revue Elev. Med. Vet. Pays Trop. 42, 115-116.

Raghvendar, S., Shukla, S.K., Sahani, M.S. and Bhakat, C. 2004. Chemical and physicochemical properties of camel milk at different stages of lactation: In International conference on saving the camel and people's livelihoods building a multi-stakeholder platform for the conservation of the camel in Rajasthan 2004 Nov 23-25, Sadri, Rajasthan, India.

Riek, A. and Gerken, M. 2006 Changes in Llama (Lama Glama) milk composition during lactation. J. Dairy Sci. 89, 3484-3493.

Riyadh, S.A., Faris, F.A., Elsayed, I., Mohammed, A.A., Ahmed, S. and Moez, A. 2012. Effects of the production system, breed, parity, and stage of lactation on milk composition of dromedary camels of Saudi Arabia. J. Anim. Vet. Adv. 11, 141-147.

Sambraus, H.H. 1995. Quantitative information on camel's suckling. J. Anim. Breed. Genetics 112, 469-479.

Sheriha, A. M. 1986. Composition of Libyan camel milk. Australian J. Dairy Technol. 41, 33-35.

Shuiep, E.S., El Zubeir, I.E.M., El Owni, O.A.O. and Musa, H.H. 2008. Influence of season and management on the composition of raw camel (Camelus dromedarius) milk in Khartoum state, Sudan. Trop. Subtrop. Agroecosy 8, 101-106.

Wafa, I.A.B. and El-Zubeir, I.E.M. 2014. Impact of husbandry, stages of lactation and parity number on milk yield and chemical composition of dromedary camel milk. Emir. J. Food Agric. 26, 333-341.

Zeleke, Z.M. 2007. Non-genetic factors affecting milk yield and milk composition of traditionally managed camels (Camelus dromedarius) in Eastern Ethiopia. LRRD, p 19. Available via https://www. lrrd.cipav.org.co/lrrd19/6/zele19085.htm 